\title{
Phenomenon of Religious Revival in the Context of the Experience of Modernization of the Muslim Community in the Late XIX - Early XX Centuries
}

\author{
Rinat A. Nabiyev ${ }^{1}$ \& Anvar A. Gafarov ${ }^{1}$ \\ ${ }^{1}$ Kazan (Volga Region) Federal University, Kazan, Russia \\ Correspondence: Rinat A. Nabiyev, Kazan (Volga Region) Federal University, Kremlyovskaya Street 18, Kazan \\ 420008, Russia. E-mail: kafpolithistory@mail.ru
}

Received: April 14, 2015 Accepted: April 20, 2015 Online Published: April 27, 2015

doi:10.5539/jsd.v8n4p253 URL: http://dx.doi.org/10.5539/jsd.v8n4p253

\begin{abstract}
The urgency of the problem under investigation is due to modern processes of religious revival, actively manifested primarily in the Muslim environment, in violent politicization of Islam, the growing influence of radical movements. The article aims to study the experience of the modernization of the Muslim community in Russia (late XIX - early XX centuries), opportunities and prospects for its reception at the present time. The civilizational approach is the leading one to the study of this problem, which allows us to consider the Muslim community in Russia as an integral part of Islamic civilization, positive changes in its socio-cultural way of life in the context of Islamic modernization processes. Based on the study of the works of Muslim modernists, the authors concluded that in the late XIX - early XX centuries they substantiated the principles of tolerance and rationalism in addressing religious issues, which have become the basis of modernization of the entire way of life of the Muslim community in Russia and an alternative to fundamentalist revival. The article may be useful in the development of training courses on the history of Islam, the Muslim peoples, the history of the Tatar people, as well as the history of culture and social thought of the peoples of Russia as a whole.
\end{abstract}

Keywords: Russia, late XIX - early XX centuries, a religious revival, modernization of Muslim community

\section{Introduction}

The phenomenon of the modern religious revival in Russia is directly linked to global social and political disasters that have befallen our country in recent times. The 20-th century ended with the collapse of the last empire and the devaluation of spiritual values of the disintegrated atheist state. It is not rhetorical questions "Who are we?", "Where?" And "Where are we going?" reflected the crisis of human identity of the post-Soviet era, his appeal to the saving, but almost lost religious traditions. Spasmodic attempts to connect "decomposed times" today lead to an active spiritual quest and diverse socio-cultural projects. In most cases the above-said concerns Muslemism, which suffered mostly during the Soviet period. Having stopped at the turn of 1917 , however, the Islamic revival is also due to the fact that the process of modernization of the Muslim community (XIX - early XX centuries), passing the stage of technological, social and cultural modernization in part, is not complete. The stage of mental modernization was delayed and gets its solution only for the time being.

After a hundred of years Muslim ideas of modernism (Jadidism) aimed at the renewal of the lifestyle of the Muslim community, remain in demand as never before. Actively developing processes of religious revival, both in Russia and other countries of the former Soviet Union once again raised questions about the place of Islam and the Muslim Ummah in the modern society, on how to integrate Islamic religious and spiritual values and cultural traditions in the modern world (Mukhametshin, 2005). It is obvious that once again the Russian Islam is on the verge of the next upgrade and a new round of reforms. On this evidence, those of the historical traditions and Jadidism achievements are not only invaluable experience of reforms for modern national elites and generations of Muslims in general, but the system of principles, methods and approaches related to the modernization of the Muslim community (Nabiev et al., 2010; Gafarov, 2014). The question about the reception of Jadidist views in today's motion to renew the life of Muslims arose not by chance. The phenomenon of "neodzhadidizm" sparked heated debate in the modern Muslim society (Nabiyev, 2002, 2014), which is accompanied by a permanent appeals to the era of classical Jadidism, disputes about its essence and meaning. 


\section{Methodological Framework}

The methodological base of the article is presented by a civilizational approach, the fundamental provisions of which define a conceptual outline, the structure of the theoretical and methodological assumptions of the trends of development of the Muslim community in Russia. The authors consider Russian Muslims to be an integral part of Islamic civilization, with its archetypical traits, positive changes in their socio-cultural way of life - in the context of the Islamic modernization processes.

Methodological bases are due to the purpose of the article, which determined the appeal to system-integrated approach, its essential elements: structural and functional, dialectical, typology, logical, hermeneutic, phenomenological, comparative-historical method. In the study and presentation of the material scientific methods (logical, comparison methods, classification, analysis and synthesis), were used as well as special ones diachronic (the method of periodization), problem, chronological- problem, the method of simultaneous analysis. The specifics of the study, its interdisciplinary nature require the use of methods of cultural, religious studies, of source and other humanities. These approaches make it possible to identify the essential aspects of the general and specific features of the modernization of the Russian Muslims of the late XIX - early XX centuries in line with the general processes of religious revival.

However, complex search of terminology definitions highlighted the different approaches of national historiography to the study of the processes of adaptation of the Muslim community to rapidly changing conditions of life. Marxist commitment to universalization in understanding the diverse historical process inevitably encouraged to seek, if not identical, then at least similar parallels in the development of European and Islamic civilizations. As a result, the term "Islamic Reformation" becomes very popular in the scientific literature 1960-80 years; (Gordon Polonskaya, 1963) Levin, 1972; Stepanyants, 1974 et al.) that seems artificial extrapolation. It should be taken into account that the contents of the "European reform" is not identical to in appearance similar processes that took place in the Muslim world in the XIX century. The treatment of the internal logic of the development of Islamic civilization subsequently led to the abandonment of universal Eurocentric "bindings". (For example, Stepanyants M. T., a leading philosopher and orientalist (Stepanyants, 2001) moved away from the use of the term "Islamic Reformation", despite the active defense of it in his early work. Z.I. Levine's t views also underwent quite remarkable evolution. His cautious reservations of the early $70 \mathrm{~s}$ that "there should be no parallel between the religious and ethical movement of Islamic Reformation and known socio-political movement of the XVI century in Western Europe" (Levin, 1972), in the early 90s changed into the term "Muslim reformism" (but "reformation of Hinduism"). (Levine, 1993) and, finally, at the end of the 90s the term oriental "reformation" (Levin, 1998) was abandoned.

Currently, the most commonly used terms are: modernism or reformism presented in scientific literature as identical, which in our opinion is not quite correct. Modernism is considering a wider range of issues beyond the face of religious and social subjects. In the semantic terms modernism, defines primarily target (improvement corresponding to modern requirements), reformism also draws attention to the means of achieving it. We can not agree also with the identification of "modernism" and "Europeanization", and correspondingly narrowed the process to the movement of persons who have received a European education, which is closely related to the Western way of life and do not have the broad support (Stepanyants, 1974). "Modernism", which is a much broader concept of "Europeanization" is not merely "a copycat," which refers to the "acculturation", but an organic innovations processing, including, inter alia, borrowing from other cultures.

It should be noted that in the Russian literature of the Soviet period there was a quite tough tradition of use of the basic terms of the Islamic era of modernization. With regard to the processes of the Muslim East such terms as Reformation, enlightenment, modernism were used. In relation to similar phenomena in the environment of the Muslim peoples of Russia the use of the terms reformers, Jadida, new method (Validi D.), reformation, Renaissance, Renaissance (Ibragimov GG) new methods, a new ideology (Vorobyov NI, Ishaki GG .), innovation, enlightenment, reformism, Jadidism was common. The latter, on the the assertion of a number of scientists, is a Turkic Muslim kind of modernism that emerged in Russia in the late XIX - early XX centuries (Martynenko, 2005). It is possible to draw parallels with the Arab Nahda movement that swept the Middle East in the second half of the XIX century. Kirillina S.A. evaluates Nahda as "a comprehensive process, the source of which was in addition to the benefits of culture, science and practice of the West" glorious Arab heritage "national spiritual riches" (Kirillina, 1989). However, despite the overlap, the basic terminology is practically does not intersect throughout the various stages of the development of Soviet historiography.

With regard to the Muslim peoples of Russia, the terms "Reformation, the reformers" are widely used, especially in 1920-30. But in the post-war period the terms "Enlighteners, the Enlightenment." completely dominated. 
However, the terms "Reformation, the reformers" are widely asserted in literature on general Orientology. We can assume that this differentiation is primarily linked to the ideological and methodological aims of the past. In its quest to "associate" theoretically historical destinies of peoples of the country the official doctrine avoids historical parallels, beyond the limits of indicated unity.

If in the works on the history of philosophy, general history of the edge between modernism and reformism, look really shaky and uncertain, the current literature on the history of the Muslim peoples of the Russian Empire considers reformism as a religious and intellectual, religious and social movement. Proceeding from this basic promise the basic subjects of muslim modernization in Russia were composed: religious reformism, enlightenment, Jadidism where the latter, is generally perceived as a developed phase of the previous stages and the stage of transition to a political modernization. In this scheme not so much a succession of stages is reflected, as a change of emphasis within a complex of manifold process. Each previous stage, creating the conditions for the following one, however, does not disappear, but continues to grow and have a significant impact on the overall motion; but at the same time with the expansion of a general movement the specific component of the early stages gradually dissolves in a more global processes.

\section{Results}

Taking into consideration the urgency, of especially mental modernization we will focus on the fundamental provisions put forward by the Muslim modernists in the late XIX century (Devlet Kildeev, Aleem Mirza, A. Baiasitov et al.), which may not have been adequately assessed before, but certainly are demanded currently. The key concept to resolve a number of philosophical problems is tolerance, which is now recognized as one "of the basic humanistic principles of Islamic civilization" (Zarrinkub, 2004). Muslim modernists are actively pursuing the idea of no antagonism (and even the presence of proximity) between Islam and Christianity. Devlet Kildeev, one of the first modernist thinkers calls Judaism, Christianity and Islam three daughters of the Old Testament, recognizing that the Muslim religion - "is a full, although the younger sister of the two religions, and based on the Old and the New Testament teaching "(Delved Kildee, 1881). "Islamism - he says - is based on the teachings of the Bible and the Gospel" (Delved Kildee, 1881). Aleem Mirza in principle considers Islam as a common name, of the Abrahamic religions. According to him, Muhammad did not create Islam, the faith of Abram was before him in the form of Judaism and Christianity; "He did not come to destroy the truths of the Bible and the Gospels, but came to back them up and give them a greater development" (Mirza Alim, 1882). The author adds that "Muhammad is the same messenger or apostle of God, Moses, Jesus and other prophets", who escaped under the pseudonym Muslim (Muslim, 1883).

On the basis of unity (in "spirit and intent") and the consistency of the Abrahamic religions, universal spiritual--cultural values, the Muslim modernists urged the faithful to overcome the false set of its uniqueness and cultural alienation from the non-Muslim peoples. For, as the enlightener S. Abdugafarov asserts, that isolation leads only to an increase in self-esteem, "and self-esteem leads to stagnation" (Ostroumov,, 1890). "Not religious values, and" only various human concepts, judgments and opinions separate people"(Devlet Kildeev, 1881), " The Church stands next to the mosque in the villages and towns; each of them calls to the same Almighty "(Bayazitov, 1891).In the second half of the XIX century A. Bayazitov being perhaps one of the most consistent modernist reformers, wrote: "So, we see in the teachings of Islam that for proper earthly life and heavenly bliss there is no distinction of any nation, any religion. All Almighty gave his benefits to all; and mercy of the Lord is enough for everyone "(Bayazitov, 1898).

Accordingly, fanaticism and aggressiveness, which was accused (and is still accused) by its detractors is initially alien to Islam. In the papers "Objection to the speech of Ernest Renan" (1883), "The attitude of Islam to science and to the Gentiles" (1887), as well as in a number of articles Bayazitov stressed that "it's strictly forbidden to kill, rob and oppress civilians from Christians or Jews". "Codes of legal doctrines of Islam read that: 1) The Unorthodox' claims are more terrible to justice of God than the claims of the orthodox. 2) Their blood is like our blood; their property is as well our property. 3) What is for us, so much is for them. "These were the "personal relationship of Muhammad (and his associates, according Bayazitov - A.G.) to the Gentiles" (Bayazitov, 1886). Fanaticism, if he is, he says, does not "expire from religious hatred teachings of Islam and Christianity"; its source is ignorance (Bayazitov, 1891). "Every religion, which gives the Supreme Being concept, making it moral based on its principles is worthy of respect" (Bayazitov, 1885).

Stressing the open nature of Islam (as developing science), the lack of religious barriers to cultural exchange and perception of the achievements of world civilization, the modernists saw the cause of the backwardness of many Muslim nations from the Europeans in the fact that they took the truth wherever it was, unable to cope with the nationality or religious source. Meanwhile, the Muslim nations as a result of misunderstanding of the doctrine of 
the immutability and infallibility of the laws are reluctant to accept innovations and reforms of modern civilization, if the reforms are not mentioned in the Quran, although interpreters of the science have repeatedly explained that "he makes all sorts of changes in the civil life of Muslims, due to time and necessity, as society itself is the best judge in this matter" (Devlet Kildeev, 1881). Appealing to the prophet, Devlet Kildeev writes: "Fortunately for the progress of Muslims, Mohammed himself gave them the opportunity to every reform and to any modification, proclaiming that at his discretion " God is always may replace all of given to them by the best, which as mentioned above, " gave rise to its interpreters, to admit the legitimacy of any civil reforms, as long as they agree with the basic religious dogma "(Devlet Kildeev, 1881).

The problem related to innovation and reform in the Muslim community is relevant at the moment. To what extent the reform of the Muslim way of life is permissible, and for what edge Islamic identity varies? (Why, is, for example, babizm ahmadiyat is believed a modernized sect in the bosom of Islam and the Bahai's faith a new religion?). In Russia in the context of contemporary modernization a most broad range of opinions and directions manifested itself: from extreme traditionalism to the concepts of "Euro-Islam".

Mirza Alim in their arguments based on the fact that "Islam is an expression of the eternal absolute truth," the existence of God and the immortality of the soul single "truths that lie at the heart of the spiritual nature of every man, and who preached at all times, people and the prophets chosen by God."

Accordingly, "the truth of Islam, which are in the Bible, the Gospel and the Koran by themselves do not need any reforms and amendments, which are entirely attributable only to the development of a true understanding of these truths, as a result of a subtle but constant forward movement of human thought in its cultural development" (Mirza Alim, 1882). Leading to the idea of the historical relativity of ritual attribute and public order, and Aleem Mirza Devlet Kildeev urge Muslims imbued more with a spirit and meaning of Islam than its outer side. Jadid A. Fitrat, calling for unity "with all Muslim societies", suggested to " consider "all who accept the creed to be Muslims ..., no matter to what sect they belong " (Klimovich, 1936).

However, such an approach is still the stumbling block of fundamentalist modernism of the religious reformation that puts the letter of the Qur'an up the spirit and meaning of Islam. Zaynulla Ishan Rasulev strongly condemned literalist views of Wahhabism ideologists. In his book "Makalyat Zayniyyah" (1908), he showed the theoretical origins of Wahhabism - numerous works of Ibn Taymiyyah and his disciples. Criticizing his teaching position (on a number of issues about the phenomenon and the return of the prophets, God in Islam et al.), Rasulev noted that "his followers went on his ideology and added even more fallacies" (Rasulev, 2011).

In solving the problems associated with the perception of new phenomena modernists based on the principle of ijtihad (al-Mutlaq al-ijtihad), allowing the imposition of an independent judgments about the basic questions of faith and socio-legal life of Muslims. "The opening of the gates of ijtihad" had revolutionary implications for the fate of the Islamic civilization, especially in terms of the emancipation of intellectual thought. The revival of this law was widely supported in the Muslim religious reform environment of XIX century (A. Kursavi, S.Mardzhani, Bigiyev M. et al.) In the book "Islam and Progress" like its predecessors Bayazitov also called for the restoration of the original principles of free early Islam, involving ijtihad (Bayazitov, 1898). Unthinking, uncritical adherence to authority, in principle, becomes bad manners. In the notes to the "Rihlat al-Marjani" ("Journey Marjani," 1898, commenting on the phrase "You do not have the knowledge, because you just follow the authorities," said during an impromptu debate, ) R. Fahretdin exclaims: "It is right to say" (Yuzeeva, 2003).

Recourse to ijtihad is definitely connected with the elements of rationalization of religious and intellectual life of Muslims. Based on the position that "Islam is a positive definite and precise doctrine" Bayazitov, like his predecessor, refers to a purely rational principles of theological problems perception for the mind "is a light from the light of God" (Bayazitov, 1883). As the "doctrine of our Prophet Muhammad ... does not contradict the logic of common thinking and is not afraid of science," "ultimate ideal of humanity, and the ultimate goal of its development on the Earth - is the union of religion and science, these higher spheres of the human mind" (Bayazitov, 1883). Mirza Aleem also defends the position that "Islam, properly understood, is able to lead his followers to enlightenment and civilization"; "The cause of stagnation and ignorant state of mostly Mohammedan peoples needs to be looked for in other than Islam and Mohammedan religious form, guided by the consideration that every religious idea loses its life-giving influence on the development of the spiritual powers of man, if it is obscured by the real rites" (Mirza Alim, 1882).

The former Kokand kazy Sattar -khan Abdugafarov did not confine to stating the consistency of scientific knowledge to Islam. "Scientific knowledge is not only contrary to the teachings of Islam, - he says - but makes it more clear to our minds and helps us to better perform the purpose of religion" (Abdugafarov, 1887). In another article Sattar- Khan commented that "with the acquisition of (scientific - A.G.) knowledge ("Sharia law, 
mathematics, medicine, astronomy and other sciences") it will be possible for people to comprehend the work of his Creator and his perfect power". "Only then we will fulfill all determinations of our All mighty Lord (God) and to know ourselves", using this knowledge for the benefit of the people themselves (Abdugafaovr, 1885). It is obvious that the public benefit in modernists' representations becomes a fundamental criterion of truth.

The success of the Muslims reform movement of inner Russia stimulated a similar trend in Kazakhstan and Central Asia. Ideas of religious and intellectual renewal are present in the works of the enlighteners Akmulla, Abay Mukimi et al., "Human knowledge is carried out thanks to the love of truth and righteousness, - wrote the Kazakh poet - passion to penetrate the root and the hidden meaning of each phenomenon. It should be a passion not to the knowledge of religious dogma, but to know the truth of things. Only this gives a person the knowledge satisfying his human dignity. For this is the love of God ..." (Abay, 1996). Ijtihad ideas are more and more clearly heard in his work: "to be established in Iman, two conditions are necessary: first, the belief must be conscious, secondly, on learning from the books and hearing from mullahs it is necessary to develop one's own understanding and be resistant in it and not to believe anybody's instigation" ("we should not forget that in addition to the two kinds of faith - conscious and unconscious - there is no third faith") (Abai, 1995). Otherwise, "if we do not have a free mind, how can we understand the divine word ...? Where does said by the God go: who wants to know me will know me only by his mind?" (Abay, 1995).

Recognizing Sharia excellence, a prominent reformer M. Bigiyev nevertheless advocated ijtihad, Fiqh and justice reform. In his work "My view of the Islamic Sharia" Bigiyev wrote: "The school of fiqh based with a view to ordering of human existence in all its forms cannot be neither eternal nor all-inclusive. Therefore, a decision that was true at a certain time for a certain situation and certain people are not always necessarily true for the events and people in later centuries "(Khairutdinov, 2000). Bigiyev also maintained talfika policies ( judgments synthesis of four schools of thought) and maslaha (the common good). The need for synthesis mazhabs was arguementated by the public interest priority. "If the decision of one of the schools of thought on any subject puts you in a difficult position, - instructed reformer - then we should certainly reject this decision. Fanatical adherence to statutes that may cause damage to some or other aspects of our social status, of course, is a sin "(Khairutdinov, 2000).

Accordingly Bigiyev gently shifted its focus towards the ijma. Based on the fact that it is necessary to "take into account as evidence historical experience, life experience, reason, needs, needs of society, the requirements of the time" (Khairutdinov, 2000), he argued that this Ummah shall be entitled to ijtihad and lawmaking, because "ijma of the Ummah is without blemish. The right way, the truth and pleasing to God cannot be out of the Ummah consensus "(Khairutdinov, 2000). However, in respect of ijma of the Ummah Bigiyev warned that "due to the changeability of time, place and arising from these differences, it can never have a quality of eternal establishment" (Khairutdinov, 2000). In respect of legal proceedings Bigiyev, came out strongly to condemn the Institute of sheyhulislamism. "The Muslim Institute of sheyhulislamism, - he wrote - in the face of all of its employees was a means or leader of all vices," "in all small and large infidelity and vice, Sheikhulislam, Sharia judges and ministers of religion" played the first role" (Khairutdinov, 2000).

Thus, according to Bayazitov itself "legislative history of Islam gives a wonderful key to discovering the most complex and tricky locks. Unfortunately, this key in careless hands had become covered with mold and rust. He's waiting times, when this mold is purified and used in order to breathe new vigor to where erstwhile reality and energy are the pride of all mankind "(Bayazitov, 1898). The urgent task is to "clear teachings of Islam from the chaff, admixed to it later ignorant" (Bayazitov, 1898). However, Bayazitov understands: "We cannot go back to the old simplicity" (Bayazitov, 1898) early times. "Every innovation is accepted by people not easily, the fact which occurs in all nations. It also does in the Muslim community. "Thus, the" the idea of mental development and spread of science among Muslims is an urgent need." Talking of Islam, it is close to everything reasonable, humane, science and knowledge" (it does not "choke the science, but promotes its development") (Bayazitov, 1891). Devlet Kildeev sums up the message to the modernist descendants saying that only "in this case it is possible to predict a brilliant future for Muslims" (Devlet Kildeev, 1881).

\section{Discussions}

At the turn of 1990-2000-ies. Jadidism traditions have been the subject of intense scientific study. Along with the enlightenment and modernization of social and political consciousness of Muslims great attention has been paid to the religious reform movement, "lying" under ideological taboos up to the present time. However, the studied works of religious reformers (A. Kursavi, S.Mardzhani, Z. Kamali et al.), because of its theological and philosophical specifics were available to understanding of a narrow layer of the Muslim elite. Answering specific questions about life works of modernists- publicists, great popularizers of reformist ideas (Devlet Kildeeva, 
Murzy Alim, Bayazitova A. et al.), remained for researchers in the shadows. Though, it is publicists of the modernist sense, who, in our opinion, managed to bring religious reformism of the vicious circle of theological discourse on the broad modernization of social consciousness of Muslims.

However, the analysis of contemporary processes in the Muslim community, until recently restricted to a purely historical formulation of the question posed from the priorities of the social, socio-cultural situation of the late XIX - early XX centuries. The question of the reception of Jadid inheritance was considered mainly as a whole (in line with the discussion between modern modernists and traditionalists), without taking into account the degree of demand and topicality of certain elements of this heritage.

\section{Conclusion}

Thus, we see that the Muslim modernists, who put forward the principles of tolerance and rationality in the decision of religious issues in the late XIX - early XX centuries laid essential prerequisites for future mental modernization of the Muslim community in the rapidly changing social and economic environment. Findings contained in their works are intended to help to translate the ideals of inter-cultural, ethnic and religious cooperation, the revival of religious and cultural values in the Russian society.

\section{Acknowledgments}

The work is performed according to the Russian Government Program of Competitive Growth of Kazan Federal University.

\section{References}

Abai (Ibragim) Kunanbaiev. (1996). Izbrannoie. Almaty: Ana tili.

Abai. (1995). "Svoiu sud'bu ot mira ne taiu..." Izbrannoie. Almaty: Izd-vo "KRAMDC-Akhmet Iassaui" Kazakhskogo PEN-kluba.

Abdugafarov, S. (1887). Mysli odnogo pochtennogo musul'manina. Turkestanskaya tuzemnaya gazeta, 6 (14 fevralia).

Abdugafarov, S. (Mulla Abdulla). (1885). Slova odnogo pochtennogo musul'manina. Turkestanskaya tuzemnaya gazeta, 8,4 marta.

Baiazitov, A. (1883). Vozrzhenie na rech Ernesta Renana. Islam i nauka. Sankt-Peterburg.

Baiazitov, A. (1885). Vopros o prosveschenii inorodtsev. Vostochnoie obozrenie, 10 (7 marta).

Baiazitov, A. (1886). Po povodu musulmanskogo fanatizma. Sankt-Peterburskiie Vedomosti, 123 (6(18) maia).

Baiazitov, A. (1891). Islam i kultura. Sankt-Peterburskiie Vedomosti, 214 (9(21) avgusta).

Baiazitov, A. (1898). Islam i progress. Sankt-Peterburg.

Devlet-Kildeev. (1881). Magomet kak prorok. S-Peterburg.

Gafarov, A. A. (2014). Rossiiskiie musulmane v kontekste obscheislamskoi modernizatsii. Kazan: Izd-vo Kazanskogo Federalnogo universiteta.

Gordon-Polonskaia,L. P. (1963). Musulmanskie techeniia v obschestvennoi myisli Indii I Pakistana (kritika “musulmanskogo natsaionalizma)." Moskva: Vostochnaia literatura.

Izueev, A. N. (Ed.). (2003). Ocherki Marjani o vostochnykh narodakh. Kazan: Tatar. Kn. Izd-vo.

Khairutdinov, A. G. (Ed.). (2000). Naslediie Musa Djarullakha Bigiieva. Sbornik dokumentov I materialov. Ch.P. Kazan: Iman.

Kirillina, S. A. (1989). Islam v obschestvennoi zhizni Egipta (vtoraia polovina (XIX-XXvv). Moskva: Nauka. Glavnaia pedaktsia vostochnoi literatury.

Klimovich, L. (1936). Islam v tsarskoi Rossii. Ocherki. Moskva: OGIZ, Gos. antireligioznoie Izd-vo.

Levin, Z. I. (1972). Razvitie osnovnykh techenii obtchestvenno-politicheskoi mysli v Sirii I Egipte.: Nauka.

Levin, Z. I. (1993). Razvitie obschestvennoi mysli na Vostoke. Kolonialnyi period XIX-XXvv. Moskva: Nauka.

Levin, Z. I. (1998). Rytsar svobodnoi mysli. Moskva: IV RAN.

Martynenko, A. V. (2005 Bahai i akhmadiyat: novyie religiozhyie soobschestva v kontekste modernizatsii islama ( sravnitelno-istoricheskii analiz). Ulianovsk: Ulianovskii Dom Pechati.

Mukhmetshin, R. (2005). Islam v obschestvenno-politicheskoi zhizni tatar I Tatarstana v XX veke. Kazan: 
Tatar.kn. izd-vo.

Murza Alim. (1882). Islam i magometanstvo. Sankt- Peterburskiie Vedomosti, 188 (14 iiulia); 196 (22 iulia); 239 (5 sentiabria).

Musulmanin. (1883). Musulmanstvo I razionalizm. Vostochnoie obozreniie, 24(16 iiunia).

Nabiiev, R. A. (2002). Islam I gosudarstvo: Kulturno-istoricheskaia evoluziia musulmanskoi religii na Evropeiskom Vostoke. Kanzan: Izd-vo Kazansk. un-ta.

Nabiiev, R. A. (2014). Vlast'I religioznoie vozrozhdeniie. Kazan: Kazan. Un-t.

Nabiiev, R. A., Gafarov, A. A. \& Tsiunchuk, R. A. (2010). Rossiiskiie musulmane v etnokonfessionalnych prozessakh XIX-XXI vv: kollektivnaia monografiia i sbornik vystuplenii na nauchnoi konferentsii, posviaschionnoi pamiati akademika AN RT R.I. Nafigova. Kazan: Izd-vo MO i N RT.

Ostroumov, N. P. (1890). Sarty. Etnograficheskiie materialy. Vypusk pervyi. Tashkent: Izdaniie avtora.

Rasulev, Zainullah ishan. (2011). Makalat Zainiiah: Ocherki Zainullah ishana. Kiev: AIA GRUP.

Stepanianz, M. T. (2001). Vostochnaia filosofiia. VVodyi kurs.Izbrannyie teksty. Moskva: Vostochnaia literatura.

Stepanianz,M. T. (1974). Islam v filosovskoi I obshestvenoi mysli zarubezhnogo Vostoka (XIX-XXvv). Moskva: Nauka.

Zarrinkub, A. Kh. (2004). Islamskaia tsivilizazia. Moskva:OGIZ, Gos.antireligioznoie Izd-vo.

\section{Copyrights}

Copyright for this article is retained by the author(s), with first publication rights granted to the journal.

This is an open-access article distributed under the terms and conditions of the Creative Commons Attribution license (http://creativecommons.org/licenses/by/3.0/). 